\title{
Lipopolysaccharide enhances apoptosis of corpus luteum in isolated perfused bovine ovaries in vitro
}

\author{
J Lüttgenau ${ }^{1}$, B Möller ${ }^{1}$, D Kradolfer ${ }^{2}$, O Wellnitz $^{1,3}$, R M Bruckmaier $^{3}$, A Miyamoto $^{4}$, S E Ulbrich $^{2}$ \\ and $\mathrm{H}$ Bollwein ${ }^{1}$ \\ ${ }^{1}$ Clinic of Reproductive Medicine, Vetsuisse Faculty, University of Zurich, Winterthurerstrasse 260, CH-8057 Zurich, \\ Switzerland, ${ }^{2}$ ETH Zurich, Animal Physiology, Institute of Agricultural Sciences, Zurich, Switzerland, ${ }^{3}$ Veterinary \\ Physiology, Vetsuisse Faculty, University of Bern, Bern, Switzerland and ${ }^{4}$ Graduate School of Animal and Food \\ Hygiene, Obihiro University of Agriculture and Veterinary Medicine, Obihiro, Japan
}

Correspondence should be addressed to J Lüttgenau; Email: jluettgenau@vetclinics.uzh.ch

\begin{abstract}
Lipopolysaccharide (LPS), the endotoxin of Gram-negative bacteria, has detrimental effects on the structure and function of bovine corpus luteum $(C L)$ in vivo. The objective was to investigate whether these effects were mediated directly by LPS or via LPS-induced release of $\mathrm{PGF}_{2 \alpha}$. Bovine ovaries with a mid-cycle $\mathrm{CL}$ were collected immediately after slaughter and isolated perfused for 240 min. After $60 \mathrm{~min}$ of equilibration, LPS $(0.5 \mu \mathrm{g} / \mathrm{ml})$ was added to the medium of five ovaries, whereas an additional six ovaries were not treated with LPS (control). After 210 min of perfusion, all ovaries were treated with 500 iu of hCG. In the effluent perfusate, concentrations of progesterone $\left(\mathrm{P}_{4}\right)$ and $\mathrm{PGF}_{2 \alpha}$ were measured every 10 and $30 \mathrm{~min}$, respectively. Punch biopsies of the $\mathrm{CL}$ were collected every 60 min and used for RT-qPCR to evaluate mRNA expression of receptors for LPS (TLR2, -4) and LH (LHCGR); the cytokine TNFA; steroidogenic (STAR, HSD3B), angiogenic (VEGFA $121, F G F 2)$, and vasoactive (EDN1) factors; and factors of prostaglandin synthesis (PGES, PGFS, $P T G F R)$ and apoptosis $(C A S P 3,-8,-9)$. Treatment with LPS abolished the hCG-induced increase in $P_{4}(P \leq 0.05)$; however, there was a tendency $(P=0.10)$ for increased release of $P F_{2 \alpha}$ at $70 \mathrm{~min}$ after $L P S$ challenge. Furthermore, mRNA abundance of TLR2, TNFA, CASP3, $C A S P 8, P G E S, P G F$, and $V E G F A_{121}$ increased $(P \leq 0.05)$ after LPS treatment, whereas all other factors remained unchanged $(P>0.05)$. In conclusion, reduced $P_{4}$ responsiveness to hCG in LPS-treated ovaries in vitro was not due to reduced steroidogenesis, but was attributed to enhanced apoptosis. However, an impact of luteal PGF $_{2 \alpha}$ could not be excluded.

Reproduction (2016) 151 17-28
\end{abstract}

\section{Introduction}

Fertility in dairy cows has decreased for more than a half century (Walsh et al. 2011) due, in part, to inflammatory diseases (Barker et al. 1998, LeBlanc et al. 2002). Cows with endometritis have prolonged calving-to-conception intervals $(\mathrm{CCl})$ and are replaced sooner due to reproductive failure (LeBlanc et al. 2002). Furthermore, inflammation in non-genital tissues (e.g. mastitis) also prolongs $\mathrm{CCl}$ and increases the number of services per conception (Barker et al. 1998), attributed in part to activation of immune cells by bacterial cell wall components and production of cytokines (Hansen et al. 2004).

In previous studies (Suzuki et al. 2001, Herzog et al. 2012), lipopolysaccharide (LPS), the endotoxin from the outer membrane of Gram-negative bacteria, was used as a model to determine effects of inflammation on fertility in cows. Binding of LPS to toll-like receptor (TLR) 4 (Akira 2003) activates macrophages and triggers cytokine production. Furthermore, instillation of LPS in the mammary gland consistently increases systemic concentrations of cytokine tumor necrosis factor alpha (TNFA; Blum et al. 2000). In addition, exogenous LPS reduced fertility due to impairment of ovarian follicular development and ovulation (Suzuki et al. 2001, Lavon et al. 2008, Williams et al. 2008). The LH peak was significantly retarded or completely inhibited in cows given LPS during proestrus (Suzuki et al. 2001). Furthermore, LPS affected morphology and function of the bovine corpus luteum $(\mathrm{CL})$. In that regard, intravenous LPS decreased blood progesterone $\left(\mathrm{P}_{4}\right)$ concentrations (Giri et al. 1991, Herzog et al. 2012) and caused temporary reductions in both luteal size and blood flow (Herzog et al. 2012). Since $\mathrm{PGF}_{2 \alpha}$ metabolite concentrations increased after LPS treatment (Herzog et al. 2012), which was consistent with increased $\mathrm{PGF}_{2 \alpha}$ release from the endometrium during inflammation (Giri et al. 1991, Miyamoto et al. 2000, Skarzynski et al. 2000), it was speculated that enhanced uterine $\mathrm{PGF}_{2 \alpha}$ induced premature luteolysis. It was noteworthy that TNFA consistently stimulated $\mathrm{PGF}_{2 \alpha}$ synthesis in endometrial cells during all stages of 
the estrous cycle (Miyamoto et al. 2000). However, a more recent study (Mishra \& Dhali 2007) suggested that LPS might impair the $\mathrm{CL}$, independent of endometriumderived $\mathrm{PGF}_{2 \alpha}$. In that study, which used a luteal monolayer culture, LPS induced oxidative stress and decreased cell viability, although an influence of endometrium-derived $\mathrm{PGF}_{2 \alpha}$ was excluded.

In ruminants, the in vitro model of an isolated perfused ovary (IPO) was introduced several decades ago (Romanoff \& Pincus 1962, Mills \& Morrissette 1970, Stahler \& Huch 1971, Sturm \& Stahler 1971, Janson et al. 1978), mainly to investigate ovarian steroid biosynthesis and energy metabolism. For studying mechanisms of LPS action on the bovine $\mathrm{CL}$, with special consideration of the impact of uterine-derived $\mathrm{PGF}_{2 \alpha,}$ this model has important advantages. At first, compared to in vivo studies, the IPO model facilitates determining LPS effects on the $\mathrm{CL}$, excluding any influence of $\mathrm{PGF}_{2 \alpha}$ from extraluteal sources. Therefore, this model should be a good alternative to LPS, which has severe systemic effects on cows (Giri et al. 1990, Giri et al. 1991, Herzog et al. 2012). Secondly, compared to cell cultures, the IPO model enables interactions between various cell types (e.g. luteal, vascular, and stromal cells) of the bovine $\mathrm{CL}$ without changing their composition and arrangement, including an intact three-dimensional structure and intercellular communication (Brannstrom \& Flaherty 1995). Furthermore, the structural integrity of the $C L$ within the surrounding ovarian tissue was maintained in IPO (Stahler \& Huch 1971) compared to tissue culture systems.

Using the IPO technique, determination of $\mathrm{P}_{4}$ and $\mathrm{PGF}_{2 \alpha}$ in the effluent perfusate enables direct assessment of release of these hormones from the CL. $\mathrm{P}_{4}$ synthesis is the most important indicator of functional integrity of the CL (Rekawiecki et al. 2008). In that regard, increased $P_{4}$ synthesis following $\mathrm{LH}$ treatment is evidence of $\mathrm{CL}$ responsiveness (Skarzynski et al. 2008). Prostaglandin $\mathrm{F}_{2 \alpha}$ is the most effective mediator of luteolysis in ruminants (McCracken et al. 1999). During physiological luteolysis in cattle, $\mathrm{PGF}_{2 \alpha}$ is released from the endometrium as well as the CL (Shirasuna et al. 2004). Furthermore, gene expressions of steroidogenic, angiogenic, and vasoactive factors in luteal tissue provided relevant information regarding functionality of the bovine CL (Miyamoto et al. 2009, Shirasuna et al. 2010). The proinflammatory cytokine TNFA is present in bovine luteal cells, as well as in immune cells (mainly macrophages; Sakumoto et al. 2011), and is capable of reducing $\mathrm{P}_{4}$ secretion, increasing $\mathrm{PGF}_{2 \alpha}$ production, and inducing apoptosis in luteal cell cultures (Okuda \& Sakumoto 2003, Skarzynski et al. 2005).

In this study, we hypothesized that LPS directly suppresses CL function via enhanced apoptosis. Thus, the isolated perfused ovary model was established, and the impact of LPS challenge using this in vitro system was evaluated in detail.

\section{Materials and methods \\ Ovaries}

Ovaries with mesovarium were harvested from the carcasses of clinically healthy cows (Bos taurus; including Holstein Friesian, Red Holstein, Swiss Fleckvieh and Brown Swiss) that were slaughtered at a commercial abattoir. Sixteen ovaries containing a $\mathrm{CL}$ with an estimated diameter of $>20$ $\mathrm{mm}$ (subsequently confirmed as a mid-cycle $\mathrm{CL}$ ) and intact tunica albuginea as well as mesovarium with ovarian vessels were used.

\section{Preparation of ovaries}

Immediately after the ovary was recovered, the ramus uterinus and all branches of the ovarian artery with a similar diameter were ligated (Polysorb 0; Corvidien, Dublin, Ireland). Since the ovarian artery splits into small vessels and forms a convolute that surrounds the ovarian vein before entering the ovary, catheterization was performed proximal to the location where the ramus uterinus branches from the ovarian artery (Fig. 1). The ovarian artery was bluntly dissected from the connective tissue, stretched, cut diagonally, and enlarged by catheterization with peripheral venous catheters (Terumo Surflow; Terumo Europe, Leuven, Belgium) using increasing diameters (20 and 18 gauge) until a permanent 16-gauge venous catheter (Vygonüle T; Vygon, Écouen, France) could be installed. The catheter was fixed within the ovarian artery with two circular ligatures (Polysorb 0).

To avoid coagulation of blood within the vessels, ovaries were flushed with chilled $\left(4^{\circ} \mathrm{C}\right)$, heparinized (Heparin Bichsel $5000 \mathrm{IE} / \mathrm{ml}$; Bichsel AG, Interlaken, Switzerland; 150 iu heparin/ml medium) Tyrode's solution, containing 136 $\mathrm{mmol} / \mathrm{l} \mathrm{NaCL}, 11.9 \mathrm{mmol} / \mathrm{l} \mathrm{NaHCO}, 5.5 \mathrm{mmol} / \mathrm{l} \mathrm{D}(+)$ glucose $* \mathrm{H}_{2} \mathrm{O}, 2 \mathrm{mmol} / \mathrm{l} \mathrm{KCL}, 1.8 \mathrm{mmol} / \mathrm{CaCL}_{2} * 2 \mathrm{H}_{2} \mathrm{O}, 1.05 \mathrm{mmol} / \mathrm{l}$ $\mathrm{MgCL}_{2} * 6 \mathrm{H}_{2} \mathrm{O}, 0.416 \mathrm{mmol} / \mathrm{l} \mathrm{NaH} \mathrm{PO}_{4}$, and $6 \%$ (w/v) dextran 70000 added to distilled water to a volume of $1 \mathrm{I}$. Flushing was

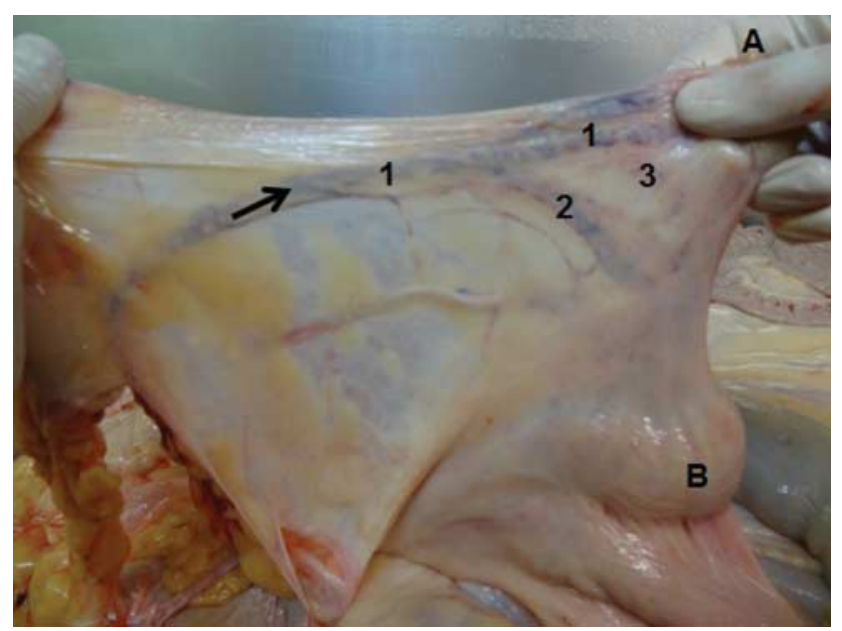

Figure 1 Mesovarium stretched between the left ovary (A) and the left uterine horn (B) to display the ovarian artery (1) with its ramus uterinus (2) and ramus tubarius (3). Catheterization was performed at the marked position $(\rightarrow)$ proximally from the location where the ramus uterinus branched from the ovarian artery. 
continued until the effluent perfusate was macroscopically clear and the color of the CL changed from red to yellow. Flushed ovaries were transported to the laboratory in icechilled heparinized Tyrode's solution.

In the laboratory, ovaries with a vascular pedicle were weighed with a precision balance (Mettler PM 400; MettlerToledo, Greifensee, Switzerland), and average diameter of the $\mathrm{CL}$ was determined with ultrasonography (Aquila Esaote Pie Medical; Esaote Biomedica, Cologne, Germany). Only ovaries with a luteal diameter $>20 \mathrm{~mm}$ were used. Ovaries were fixed with two sutures (Polysorb 0) at their extremitates tubaria and uterina on a bipod (Fig. 2). Gravity induced the margo liber of the ovary to point upwards and the margo mesovaricus to point downwards, with the free ends of the ovarian artery (catheterized) and vein (without catheter) positioned directly above a funnel.

\section{Isolated perfusion of ovaries}

Ovaries (fixed on the bipod) were put in an incubator for newborn humans (Atom Infant Incubator V-850; Atom Medical Corporation, Tokyo, Japan) to ensure perfusion under standardized microclimatic conditions (temperature, 37.5-38.5 ${ }^{\circ} \mathrm{C}$; relative humidity, $75-85 \%$ ). A schematic illustration of the complete set-up is shown (Fig. 3).

As medium for the isolated perfusion of the ovary, a modified Tyrode's solution was used (for detailed composition see Section 'Preparation of ovaries'). Osmotically active dextran 70000 was added to the original formula of Tyrode's solution to reduce intercellular edema in the ovary, as suggested (Janson et al. 1978, Bjersing et al. 1981). Tyrode's solution was oxygenated with carbogen (Oxycarbon medizinal; PanGas, Dagmersellen, Switzerland) using a hollow fiber type oxygenator (Membrana Oxyphan PP50/200; Membrana GmbH, Wuppertal, Germany). To ensure adequate oxygenation, $\mathrm{pH}$ and partial pressures of oxygen and carbon dioxide in the

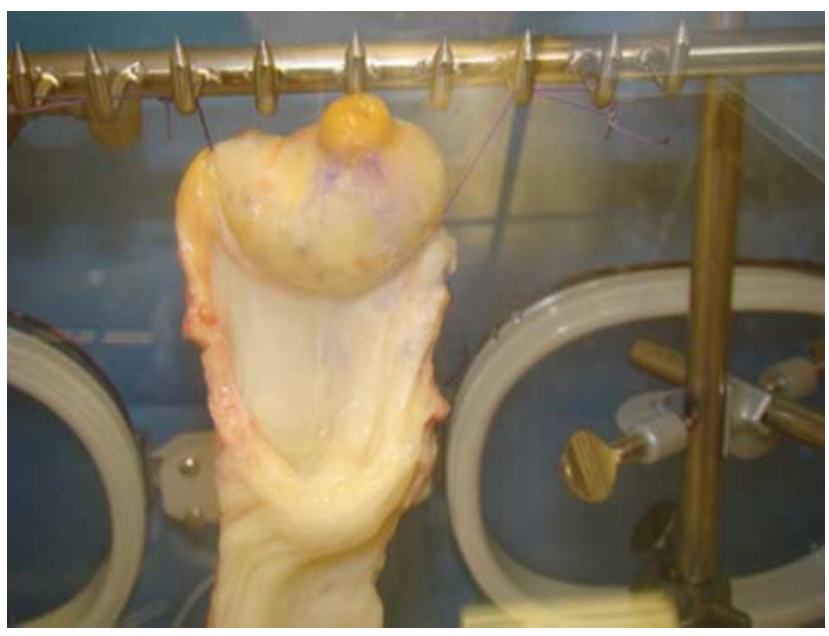

Figure 2 Position of the ovary fixed at its extremitates tubaria and uterina on a bipod with the vascular pedicle (including the ovarian artery and vein) hanging downwards. The yellow color of the corpus luteum confirmed adequate preparation after flushing with heparinized Tyrode's solution. perfusion medium before and after its passage through the ovary were measured $10 \mathrm{~min}$ after the start of perfusion, and then every $30 \mathrm{~min}$ until the end of perfusion using a blood-gas analysis system (Rapidlap 248 TM, Siemens, Munich, Germany). According to the results of blood-gas analysis, the supply of carbogen and the flow rate were adjusted to sustain a physiologic $\mathrm{pH}$ (target value, 7.40). Temperature of the perfusion medium was controlled with a Liebig condenser (GB Kühler Liebig, NSK + H14/23 120 mm; UZH Glassblowing Factory, Zurich, Switzerland) connected to a tempered water circulation (Type SSB4; Grant Instruments, Cambridge, England). Directly before entering the ovarian artery, temperature of Tyrode's solution was measured using a thermometer (WDT, Garbsen, Germany), every 5 min between 0 and 20 min after the start of perfusion, and then every $10 \mathrm{~min}$ to the end of perfusion. According to these measurements, temperature of the water circulation was adjusted to maintain the Tyrode's solution between 37 and $38{ }^{\circ} \mathrm{C}$, as reported in similar studies (Koos et al. 1984, Holmes et al. 1985, Brannstrom \& Flaherty 1995).

For perfusion, a volume- and pressure-controlled peristaltic pump (Storz Endomat n. Hamou; Karl Storz GmbH, Tuttlingen, Germany) was used. Flow was manually determined with a chronograph and a volumetric flask after 15 and $40 \mathrm{~min}$, and then every $30 \mathrm{~min}$. Pressure was continuously controlled by means of an instrument for invasive blood pressure measurement (Cardiocap 5; Datex-Ohmeda GE Healthcare Systems, Little Chalfont, England), and pressure in the ovarian artery (before entering the ovary) was calculated concurrent with flow measurements. Pressure was adjusted to achieve a perfusion flow of $\sim 2 \mathrm{ml} / \mathrm{min}$ per gram ovarian tissue, as proposed (Stahler \& Huch 1971). To avoid artifacts caused by accumulation of metabolites or hormones, Tyrode's solution was not recycled.

\section{Study design}

All ovaries were perfused for $240 \mathrm{~min}$. During the first $60 \mathrm{~min}$ (equilibration), no agents were added. In eight ovaries, 0.5 $\mu \mathrm{g} / \mathrm{ml}$ E. coli O55:B5 lipopolysaccharide (LPS O55:B5 lyophilized powder; Sigma-Aldrich, St Louis, MO, USA) was added to the medium for 180 min after equilibration, whereas the other eight ovaries were not treated with LPS throughout the entire experiment (control). For all ovaries, human chorionic gonadotropin (hCG, 500 iu; Chorulon 1500; MSD Animal Health $\mathrm{GmbH}$, Luzern, Switzerland) was added to the perfusion medium 210 min after the start of perfusion.

\section{Glucose, lactate, lactate dehydrogenase, creatine kinase, $P_{4}$, and $P G F_{2 \alpha}$}

To ensure that the ovary remained in a physiological state, glucose and lactate concentrations and activities of lactate dehydrogenase (LDH) and creatine kinase (CK) were used as markers of hypoxia and cell death (Richter et al. 2000).

Before its passage through the ovary, influent perfusion medium was sampled at $0,60,120$, and 180 min after the start of perfusion. In addition, effluent perfusion medium was sampled every $10 \mathrm{~min}$ throughout the entire perfusion period. At each time of sampling, three native aliquots and one aliquot for glucose analysis (containing sodium fluoride as a glycolysis 


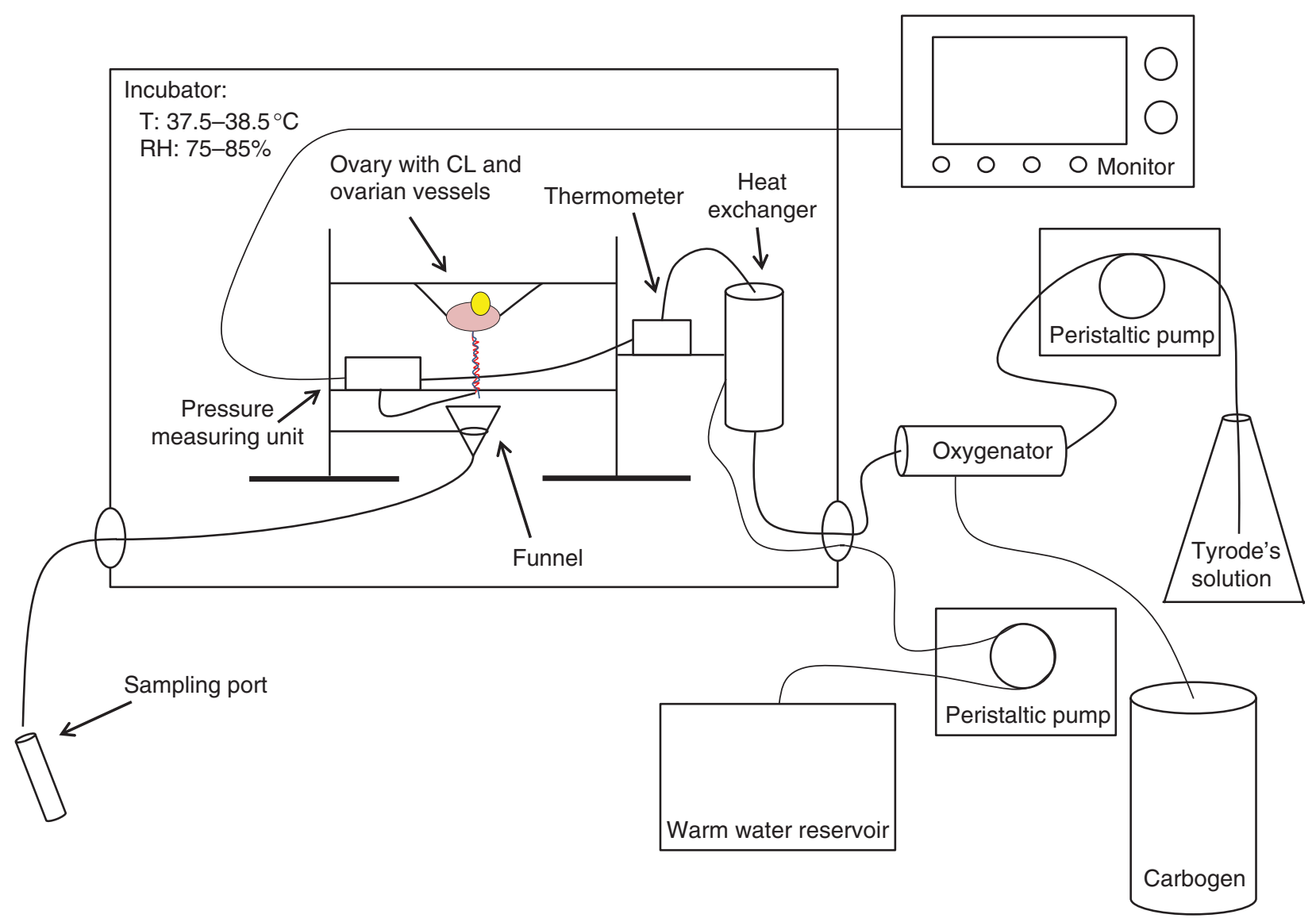

Figure 3 Schematic view of equipment used for isolated perfusion of bovine ovaries.

inhibitor; Vacuette FX Sodium Fluoride/Potassium Oxalate; Greiner bio-one, Kremsmünster, Austria) were collected and stored at $-20{ }^{\circ} \mathrm{C}\left(\mathrm{P}_{4}\right)$ or $-80{ }^{\circ} \mathrm{C}$ (glucose, lactate, LDH, CK, $\mathrm{PGF}_{2 \alpha}$ ), respectively.

Glucose concentrations were measured in all samples of influent perfusion medium. In the effluent perfusion medium, concentrations of glucose and lactate, as well as LDH and CK activities, were determined in samples collected after $10 \mathrm{~min}$, and then every $30 \mathrm{~min}$ until the end of perfusion. For these measurements, the Cobas Mira Plus analyzer (Roche, Basel, Switzerland) with kits for glucose (Glucose RTU; Biomérieux, Lyon, France), lactate (Lactate PAP; Biomérieux), LDH (LDH IFCC; Axonlab, Baden, Switzerland), and CK (Enzyline CK NAC; Biomérieux) was used. Analyses of glucose, lactate, LDH, and $\mathrm{CK}$ had a range of standard concentrations of $0.18-22.2$ $\mathrm{mmol} / \mathrm{l}, 0.04-10 \mathrm{mmol} / \mathrm{l}, 5-1200 \mathrm{U} / \mathrm{l}$, and 5-1000 U/l, respectively. Intra- and inter-assay coefficients of variation were $\leq 0.92$ and $\leq 2.55 \%$ for glucose, $\leq 1.14$ and $\leq 3.20 \%$ for lactate, $\leq 1.14$ and $\leq 1.41 \%$ for $\mathrm{LDH}$, and $\leq 2.40$ and $\leq 5.56 \%$ for $\mathrm{CK}$, respectively.

Concentrations of $\mathrm{P}_{4}$ were measured in the effluent perfusion medium every 10 min throughout the duration of perfusion, using a radioimmunoassay (RIA kit IM1188; Beckman Coulter $\mathrm{GmbH}$, Krefeld, Germany). The range of standard concentrations for this test was $0.05-50 \mathrm{ng} / \mathrm{ml}$, intra- and inter-assay coefficients of variation were $\leq 6.5$ and $\leq 7.2 \%$, respectively, and $50 \%$ of relative binding (ED50) occurred at $1.4 \mathrm{ng} / \mathrm{ml}$.
Concentrations of $\mathrm{PGF}_{2 \alpha}$ were measured in effluent perfusate at $0,10,40,70,100,130,160,190,220$, and $240 \mathrm{~min}$ of perfusion. A high-sensitivity $\mathrm{PGF}_{2 \alpha}$ ELISA kit (Enzo Life Sciences AG, Lausen, Switzerland) was used. For this test, the range of standard concentrations was $1.95-2000 \mathrm{pg} / \mathrm{ml}$, intraand inter-assay coefficients of variation were $\leq 7.2$ and $\leq 11.0 \%$, respectively, and ED50 was $81 \mathrm{pg} / \mathrm{ml}$.

\section{Corpus luteum biopsy and expression analysis}

A biopsy $(\sim 15 \times 1 \times 1 \mathrm{~mm})$ was obtained from the maximum diameter (including cells from the periphery and the center) of the $\mathrm{CL}$ after 60, 120, 180, and 240 min of perfusion, using a semi-automatic, high-speed biopsy needle (TEMNO Evolution; Fa. Walter, Baruth/Mark, Germany) that was rendered free of RNase (RNase-ExitusPlus; AppliChem, Darmstadt, Germany). Tissue samples were immediately placed in a sterile DNaseand RNase-free cryo tube (Fa. Brand, Wertheim, Germany), frozen in liquid nitrogen (Dry Shipper Taylor-Wharton CX100; Jensons Scientific, Franklin, TN, USA), and stored at $-80{ }^{\circ} \mathrm{C}$ until expression analysis was done. Immediately after the biopsy was collected, perforation points on the CL surface were closed with fibrin glue (Histoacryl; B. Braun Melsungen AG, Melsungen, Germany).

Luteal mRNA expression was determined for luteinizing hormone/choriogonadotropin receptor (LHCGR); steroidogenic acute regulatory protein (STAR); 3-beta-hydroxysteroid 
dehydrogenase $(H S D 3 B)$; TLR2 and -4 ; caspase (CASP) 3, -8 , and -9 , prostaglandin $\mathrm{E}-($ PGES/PTGES) and $-\mathrm{F}$ (PGFS/AKR1B1) synthases; prostaglandin $\mathrm{F}$ receptor $(P T G F R / F P) ; T N F A$; vascular endothelial growth factor $\mathrm{A}$ isoform $121\left(V^{2} E F A_{121}\right)$; fibroblast growth factor 2 (FGF2); and endothelin 1 (EDN1). Therefore, total RNA from luteal tissue samples was isolated and reverse-transcribed as described (Ulbrich et al. 2009) and luteal mRNA expression was determined in a two-step quantitative real-time PCR (qPCR). The qPCR was performed using the CFX384 Real-Time PCR Detection System (Bio-Rad, Munich, Germany) and the SsoFast EvaGreen Supermix (Bio-Rad). The qPCR was performed in a reaction volume of $10 \mu \mathrm{l}$, consisting of $5 \mu \mathrm{l}$ EvaGreen Mix, $0.4 \mu \mathrm{l}$ of each primer $(10 \mu \mathrm{M}), 0.07 \mu \mathrm{l}$ VisiBlue (TATAA Biocenter, Göteborg, Sweden), $3.13 \mu \mathrm{l}$ water, and $1 \mu \mathrm{l}$ cDNA. Primers used to amplify specific fragments referring to selected regulated genes are shown (Table 1). Annealing temperature (AT) and melting points (MP) are outlined. The cycle number $\left(C_{q}\right)$ required to achieve a definite SYBR Green fluorescence signal was calculated by the regression method (Bio-Rad CFX Manager 3.1). The $C_{q}$ was inversely correlated to the logarithm of the initial template concentration. The $\mathrm{C}_{\mathrm{q}}$ determined for the target genes were normalized against the geometrical mean of five reference genes (YWHAZ, H3F3A, CNOT11, SUZ12, and TBP; $\Delta \mathrm{C}_{\mathrm{q}}$ ). To avoid negative digits while allowing estimation of a relative comparison between two genes, data were presented as means \pm S.E.M. added to the arbitrary value $20\left(\Delta C_{q}\right)$. Thus, a high $\Delta \mathrm{C}_{\mathrm{q}}$ proportionally resembled high transcript abundance (Livak \& Schmittgen 2001).

\section{Postprocessing of ovaries}

After the 240-min study period, ovaries with mesovarium were weighed again to estimate perfusion-induced edema. Subsequently, ovaries were perfused with stained (Patent blue; Sigma-Aldrich) perfusion medium and dissected to test for smaller leakages and homogenous staining of the CL. Ovaries with approximately more than one-quarter of the perfusion medium leaking from the ovarian artery before reaching the ovary, and/or with poorly or non-homogenously stained $\mathrm{CL}$ were retrospectively excluded from the study. Between each perfusion of an ovary, all glassware and tubing that were in contact with the perfusion medium were cleaned and steam sterilized.

\section{Statistical analysis}

Data from only 11 ovaries were used; five ovaries (two from the control and three from the LPS group) with leakages of the ovarian artery and non-homogenously perfused $C L$ (determined with Patent blue) were excluded. In excluded ovaries, the pressure in the ovarian arteries decreased less $(P=0.03)$ during equilibration than in ovaries that were retained in the study (mean \pm s.E.M.; $22.8 \pm 10.3$ vs $44.8 \pm 4.2 \mathrm{mmHg}$ ), indicating higher resistance, probably due to intravascular coagulation. Consistently, mean $\mathrm{P}_{4}$ concentrations during the complete perfusion time were lower $(P<0.0001)$ in excluded $(68.0 \pm 6.4 \mathrm{ng} / \mathrm{ml})$ than included ovaries $(252.9 \pm 23.5 \mathrm{ng} / \mathrm{ml})$.
For included ovaries, the average interval between death of the cow and start of isolated perfusion was $79.1 \pm 3.2 \mathrm{~min}$ (range, 65-90 min), with no difference between ovaries of the control $(77.5 \pm 4.6 \mathrm{~min})$ and LPS groups $(81.0 \pm 4.6 \mathrm{~min})$. Furthermore, the ultrasonographically measured diameter of the $\mathrm{CL}$ was similar in control ovaries $(27.8 \pm 1.4 \mathrm{~mm})$ and ovaries treated with LPS $(27.5 \pm 0.7 \mathrm{~mm})$. Mean diameters and calculated cross-sectional areas of the $C L$ ranged from 25.5 to $33.0 \mathrm{~mm}$ and 5.11 to $8.55 \mathrm{~cm}^{2}$, respectively, with the exception of only one $\mathrm{CL}$ with a diameter and area of $22.5 \mathrm{~mm}$ and $3.98 \mathrm{~cm}^{2}$, respectively (for the latter $\mathrm{CL}, \mathrm{P}_{4}$ concentration in a blood sample collected immediately before slaughter was $7.2 \mathrm{ng} / \mathrm{ml}$ ). Based on cross-sectional areas ( $n=10$ ) or plasma $\mathrm{P}_{4}$ concentration $(n=1), \mathrm{CL}$ were designated as mid-cycle (Days 8-16; Day $1=$ ovulation) according to Herzog et al. (2010).

During equilibration (0-60 min after start of perfusion), pressure in the ovarian artery decreased by similar values in the control $(42.1 \pm 5.7 \mathrm{mmHg})$ and the LPS group $(47.9 \pm 6.6$ $\mathrm{mmHg}$ ), with no changes in arterial pressure during the treatment period (60-240 min after start of perfusion). The mean temperature and flow of the perfusion medium for all ovaries was $37.9 \pm 0.1^{\circ} \mathrm{C}\left(37.5-38.3^{\circ} \mathrm{C}\right)$ and $37.7 \pm 1.4 \mathrm{ml} / \mathrm{min}$ (29.3-44.5 $\mathrm{ml} / \mathrm{min})$, respectively. During the treatment period, there were no differences between control and LPS groups for temperature $\left(38.2 \pm 0.1\right.$ vs $\left.38.2 \pm 0.1^{\circ} \mathrm{C}\right)$ or flow $(38.0 \pm 2.8 \mathrm{vs}$ $36.5 \pm 1.3 \mathrm{ml} / \mathrm{min}$ ) of the perfusion medium.

In five cows of each group, the vascular pedicle started to contract frequently after a similar duration of perfusion $11.0 \pm$ 1.0 and $12.0 \pm 2.6 \mathrm{~min}$ in the control and LPS groups, respectively). Total interval of frequent contractions did not differ between cows of the control $(227.0 \pm 2.0 \mathrm{~min})$ and the LPS group (228.0 $\pm 2.6 \mathrm{~min})$. During the last hour of perfusion, an intensification of contractions (not quantified) occurred in four ovaries of the LPS group, whereas contractions became less intense in the control group. The increase in weight of ovaries with vascular pedicle (due to edema in the mesovarium) did not differ between the control (30.3 $\pm 7.2 \mathrm{~g})$ and the LPS group (47.1 $\pm 8.6 \mathrm{~g}$ ).

Analysis of $\mathrm{CK}$ had a lower detection limit of $5 \mathrm{U} / \mathrm{l}$. For measurements below this limit, $4 \mathrm{U} / \mathrm{l}$ was used as an arbitrary value to facilitate statistical analysis.

Distribution of the data was assessed visually for normality (PROC CHART) and by means of the Shapiro-Wilk-test (PROC UNIVARIATE). Because data were normally distributed, independent (between groups; PROC TTEST) and dependent (within groups; PROC UNIVARIATE) pairwise comparisons were done using a Student's t-test, in due consideration of repeated measures. All statistical analyses were done with the Statistical Analysis SystemV9.1 (SAS Institute, Inc., Cary, NC, USA), and $P \leq 0.05$ was considered significant.

\section{Results}

Mean glucose consumption during the perfusion time did not differ between control ovaries (mean \pm s.E.M.; $0.2 \pm 0.03 \mathrm{mmol} / \mathrm{l})$ and ovaries treated with LPS $(0.2 \pm$ $0.02 \mathrm{mmol} / \mathrm{l})$. On a per-time basis, glucose consumption was higher $(P=0.03)$ in the LPS group compared to the 


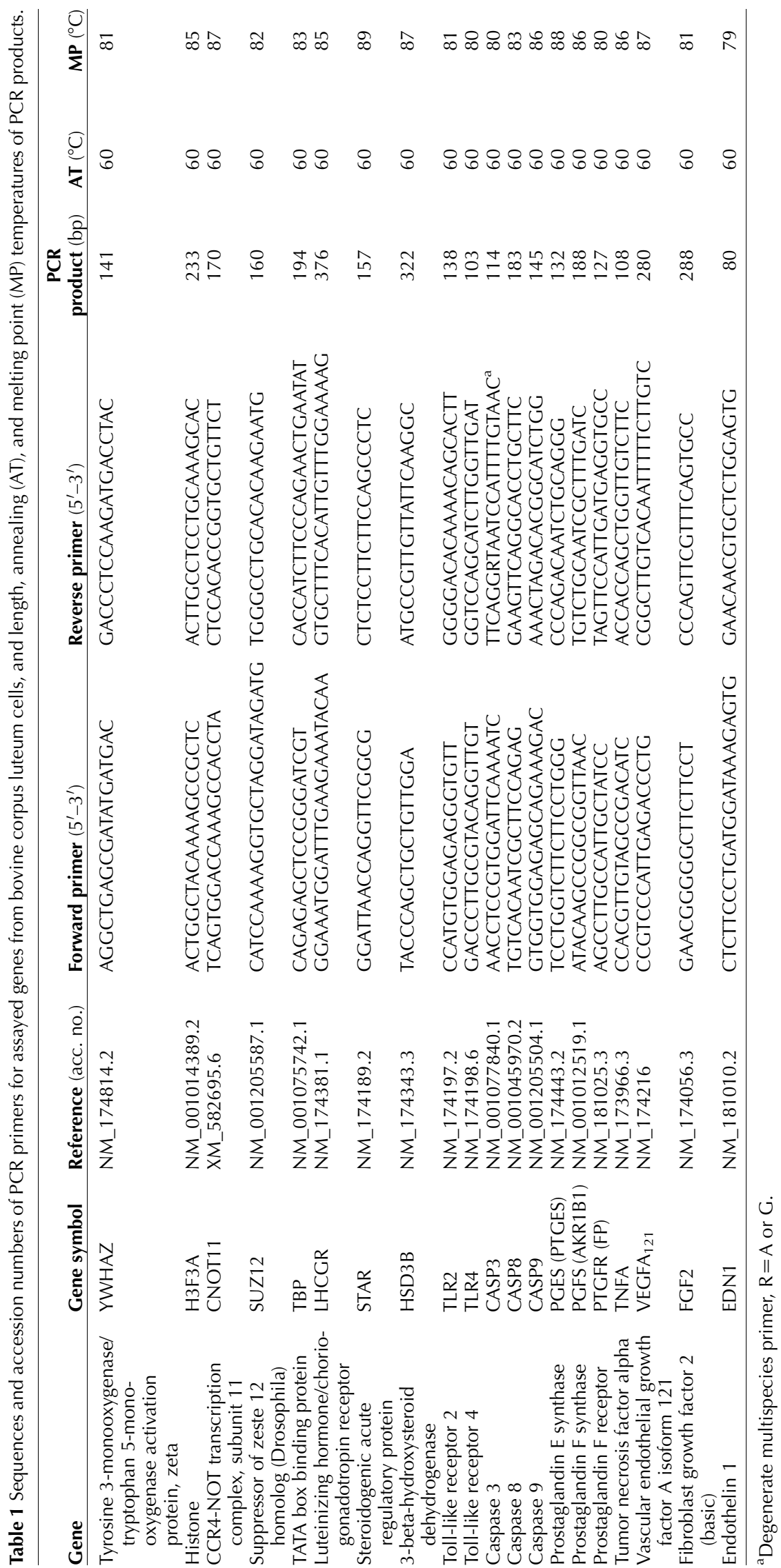


control group at 180 min after the start of LPS challenge (Fig. 4A). Average lactate production during the perfusion period was not different between ovaries of the control $(0.2 \pm 0.04 \mathrm{mmol} / \mathrm{l})$ and the LPS groups $(0.2 \pm 0.02 \mathrm{mmol} / \mathrm{l})$, but on a per-time basis, lactate concentrations were increased $70(P=0.01)$ and 100 min $(P=0.03)$ after the start of treatment in ovaries of the LPS group compared to control ovaries (Fig. 4B). Mean enzyme activities of LDH and CK decreased $(P<0.05)$ during the equilibration time to nearly half of initial values, but thereafter remained relatively constant. For control and LPS ovaries, mean activities of LDH (12.3 \pm 6.1 vs $7.3 \pm 2.6 \mathrm{U} / \mathrm{l}$, respectively) and CK $(11.7 \pm 2.3$ vs $9.8 \pm 1.1 \mathrm{U} / \mathrm{l})$ were similar throughout the entire perfusion period. Furthermore, there was no difference in $\mathrm{LDH}$ and $\mathrm{CK}$ activities between these two groups on a per-time basis (Fig. 4C and D). In summary, parameters that characterized perfusion requirements (glucose consumption, lactate production, and activities of LDH and $\mathrm{CK}$ ) were in a physiologic range at the start of the treatment period in both groups.

$\mathrm{P}_{4}$ concentrations in the effluent perfusate remained constant during the first $150 \mathrm{~min}$ of LPS treatment (mean \pm S.E.M.; $223.2 \pm 41.3 \mathrm{ng} / \mathrm{ml}$ ) and were similar to those of control ovaries $(268.5 \pm 35.0 \mathrm{ng} / \mathrm{ml})$. However, after hCG challenge (150 min after the start of LPS treatment), $\mathrm{P}_{4}$ concentrations increased in control, but not in LPS ovaries, and reached higher $(P=0.04)$ concentrations in control $(402.4 \pm 39.9 \mathrm{ng} / \mathrm{ml})$ compared to LPS ovaries $(241.9 \pm 56.8 \mathrm{ng} / \mathrm{ml}) 30 \mathrm{~min}$ later (Fig. 5).

Mean concentrations of $\mathrm{PGF}_{2 \alpha}$ did not differ between the control $(22.8 \pm 6.9 \mathrm{pg} / \mathrm{ml})$ and LPS groups

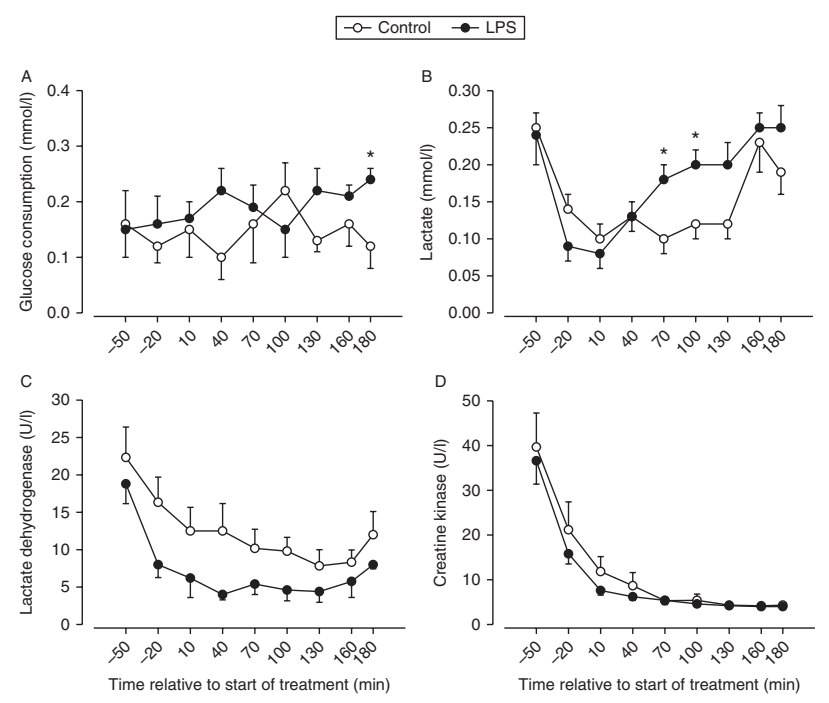

Figure 4 Changes (means \pm S.E.M.) in glucose consumption (A), lactate concentration (B), and activities of lactate dehydrogenase (C) and creatine kinase (D) of control ovaries $(n=6)$ and ovaries treated with LPS $(n=5)$ during equilibration and treatment times of perfusion. *Difference between the two groups $(P \leq 0.05)$ at times indicated.

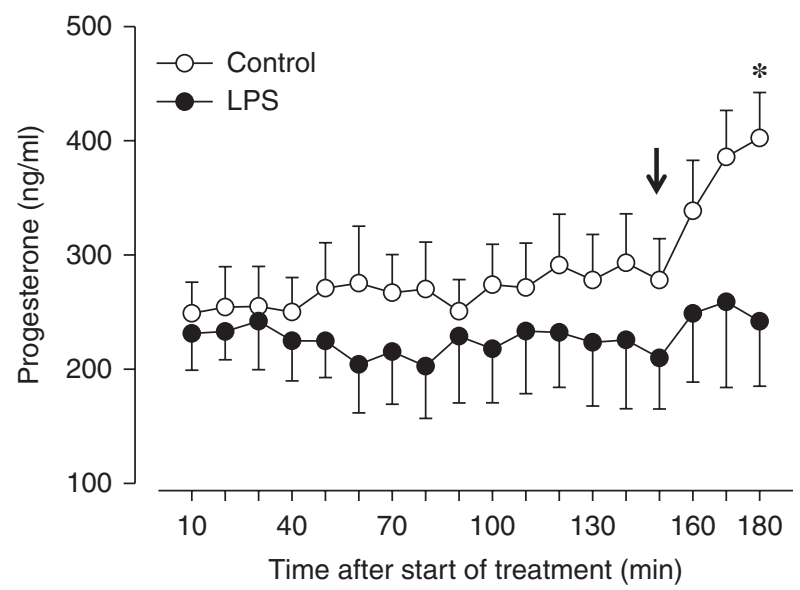

Figure 5 Changes (means \pm S.E.M.) in progesterone concentrations of the effluent perfusate from control ovaries $(n=6)$ and ovaries treated with LPS $(n=5)$ during the treatment period of perfusion. $\rightarrow$ Treatment with 500 iu hCG. *Difference between the two groups $(P \leq 0.05)$ at times indicated.

$(53.0 \pm 18.5 \mathrm{pg} / \mathrm{ml})$ throughout the entire treatment period. Furthermore, there was no significant difference in $\mathrm{PGF}_{2 \alpha}$ concentrations between ovaries treated with LPS and control ovaries on a per-time basis (Fig. 6) but $\mathrm{PGF}_{2 \alpha}$ concentrations tended $(P=0.10)$ to be higher in LPS compared to control ovaries at $70 \mathrm{~min}$ after LPS challenge. After hCG challenge, $\mathrm{PGF}_{2 \alpha}$ concentrations did not change within LPS and control ovaries.

Changes in mRNA expression of all investigated parameters are shown (Fig. 7). Luteal mRNA expression of steroidogenic factors STAR and HSD3B did not differ between the control and the LPS group for any time of analysis (Fig. 7A). Furthermore, expression of LHCGR did not differ between groups at any time (Fig. 7A). However, mRNA expression of TNFA in the LPS group was higher at $60(P=0.0002)$ and $120 \mathrm{~min}(P=0.004)$ after the start of treatment compared to the control group (Fig. 7B). Furthermore, luteal expression of TLR2 was higher $(P=0.03) 180 \mathrm{~min}$ after the start of treatment in the LPS compared to the control group, whereas expression of TLR4 did not differ between groups at any time (Fig. 7B).

Analysis of apoptotic factors revealed higher mRNA expression in the LPS group for CASP3 at $60(P=0.02)$, $120(P<0.0001)$ and $180 \mathrm{~min}$ after start of treatment $(P<0.0001$; Fig. 7C). Higher expressions were also observed for CASP8 at $60(P=0.05)$ and $180 \mathrm{~min}$ $(P=0.01)$ after the start of LPS treatment compared to control ovaries, although CASP9 did not differ between groups at any time (Fig. 7C).

Whereas mRNA expressions of PGES and PGFS were higher in the LPS group at $120(P=0.008$; only $P G E S)$ and $180 \mathrm{~min}(P=0.03$ and $P=0.05$, respectively) compared to the control group, expression of PTGFR did not differ between groups during the treatment period (Fig. 7D). Luteal mRNA expression of angiogenic 


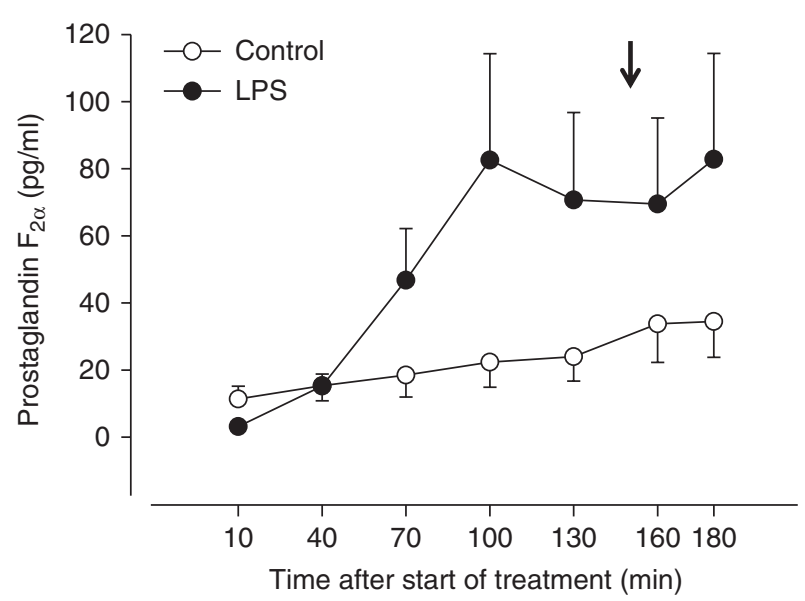

Figure 6 Changes (means \pm S.E.M.) in prostaglandin $F_{2 \alpha}$ concentrations of effluent perfusate from control ovaries $(n=6)$ and ovaries treated with LPS $(n=5)$ during the treatment period of perfusion. $\rightarrow$ Treatment with 500 iu hCG.

factor $V E G F A_{121}$ was higher $(P=0.05)$ at 60 min after the start of treatment in the LPS compared to the control group (Fig. 7E). In contrast, expressions of FGF2 and EDN1 did not differ at any time between the control and the LPS group (Fig. 7E).

\section{Discussion}

In the present study, great efforts were made to maintain energy metabolism and viability of the ovaries similar to a physiological situation in vivo during the 3 -h interval after equilibration. Therefore, the duration of ischemia was kept to a minimum, with an effort to maintain physiologic pressure in the ovarian artery, glucose consumption, lactate production, and LDH and CK activities to control vascular resistance (arterial pressure), oxygenation (glucose, lactate), and cytolytic tissue processes (LDH, CK), as suggested (Stahler \& Huch 1971, Richter et al. 2000). Arterial perfusion pressure decreased markedly during equilibration but remained stable thereafter, indicating normalization of vascular resistance after re-perfusion. Furthermore, comparable metabolic activities in ovaries of the control and the LPS group were inferred, based on similar glucose consumption between groups. Lactate concentrations decreased directly after the start of perfusion in both groups. High lactate concentrations before perfusion were attributed to initial hypoxia (Ahren et al. 1972); therefore, re-perfusion with oxygenated medium decreased lactate production to physiologic values before the start of the treatment period. High concentrations of LDH and CK, as indicators of cell death during ischemia, decreased to a low and constant level within the equilibration period, consistent with a study on isolated perfused human uteri (Richter et al. 2000). In conclusion, there was good evidence that after equilibration, the general conditions were relatively physiologic, and therefore, results obtained during the treatment period were reliable.

Increased lactate concentrations 70 min after the start of LPS challenge and the higher values in the LPS compared to the control group indicated increased metabolic activity, attributed to LPS-induced activation of immune defense mechanisms. Higher glucose uptake in the LPS group at the end of the perfusion period, which also indicated increased metabolic activity, was probably due to intensified contractions of the vascular pedicle in the LPS group compared to the control group. Consistently, rhythmic contractions (2- to 3-min intervals) of the vascular pedicle and the hilus area of the ovary were clearly visible in isolated perfused sheep ovaries and the vascular pedicle was responsible for a non-negligible portion of glucose uptake (Janson et al. 1978).

Luteal mRNA expression of TNFA was significantly higher in ovaries treated with LPS than in control ovaries 60 and 120 min after the start of treatment. Consistently, LPS induces TNFA production and the activated cytokine cascade (involving TNFA) mediates the acute phase response to endotoxins (Kushibiki 2011). Functional TNF receptors were present in steroidogenic and endothelial cells of bovine CL (Okuda et al. 1999, Okuda \& Sakumoto 2003). Therefore, the ability of TNFA to modulate the lifespan of the bovine $C L$ may largely depend on the direct action on CL cells (Skarzynski et al. 2007). In cultured steroidogenic luteal cells, TNFA inhibited gonadotropin-stimulated secretion (Benyo \& Pate 1992), consistent with failure of LPS-treated ovaries to increase $\mathrm{P}_{4}$ concentrations after challenge with hCG in the present study. Furthermore, TNFA acting via TNF receptor-1 induced apoptotic death of steroidogenic and endothelial cells of the bovine $C L$ through inactivation of the anti-apoptotic protein $\mathrm{Bcl}-2$ and by stimulating expression and activity of CASP3 (Skarzynski et al. 2005). Consistently, CASP3 mRNA expression was increased 60, 120 and $180 \mathrm{~min}$ after the start of treatment in the LPS group compared to the control group. Furthermore, mRNA expression of CASP 8 was increased 60 and 180 min after the start of LPS treatment, whereas CASP9 mRNA expression did not differ between LPS and control groups, suggesting the importance of the extrinsic (death receptor mediated) pathway of apoptosis.

$\mathrm{P}_{4}$ concentrations in the effluent perfusate did not significantly change during the first $150 \mathrm{~min}$ after treatment with LPS (similar values in the two groups). In a previous study on isolated perfused bovine ovaries (Sturm \& Stahler 1971), $\mathrm{P}_{4}$ concentrations in the perfusate of untreated ovaries were 175-291 ng/ml, indicating adequate luteal release of $\mathrm{P}_{4}$ in the present study. Previously, measurements of $\mathrm{P}_{4}$ content in luteal tissue before and after in vitro perfusion indicated that changes in $\mathrm{P}_{4}$ concentrations of the effluent perfusate resulted from differences in $\mathrm{P}_{4}$ synthesis and release and 
A Steroidogenic factors and gonadotropin receptor
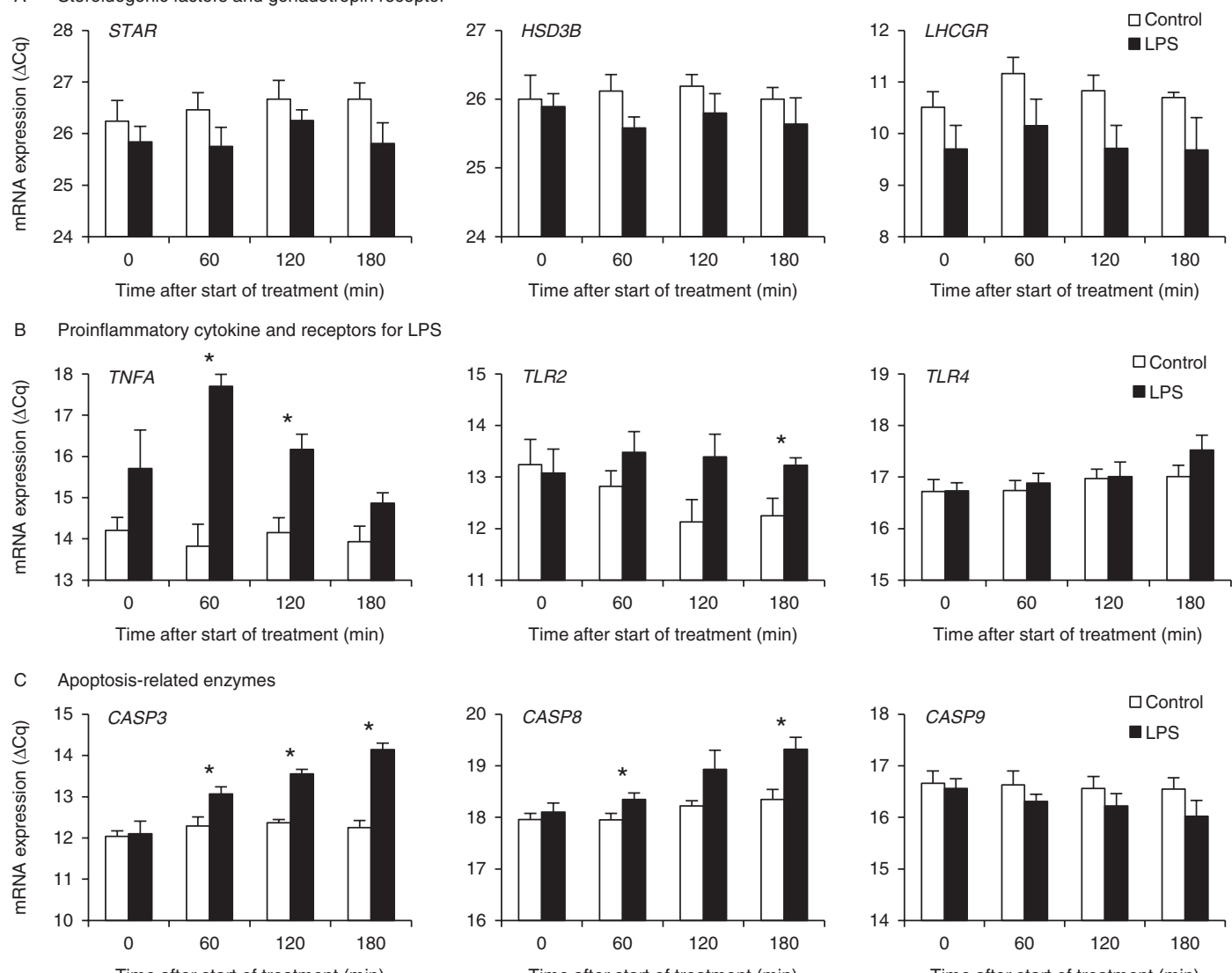

Time after start of treatment (min)

Time after start of treatment (min)

Prostaglandin-related factors
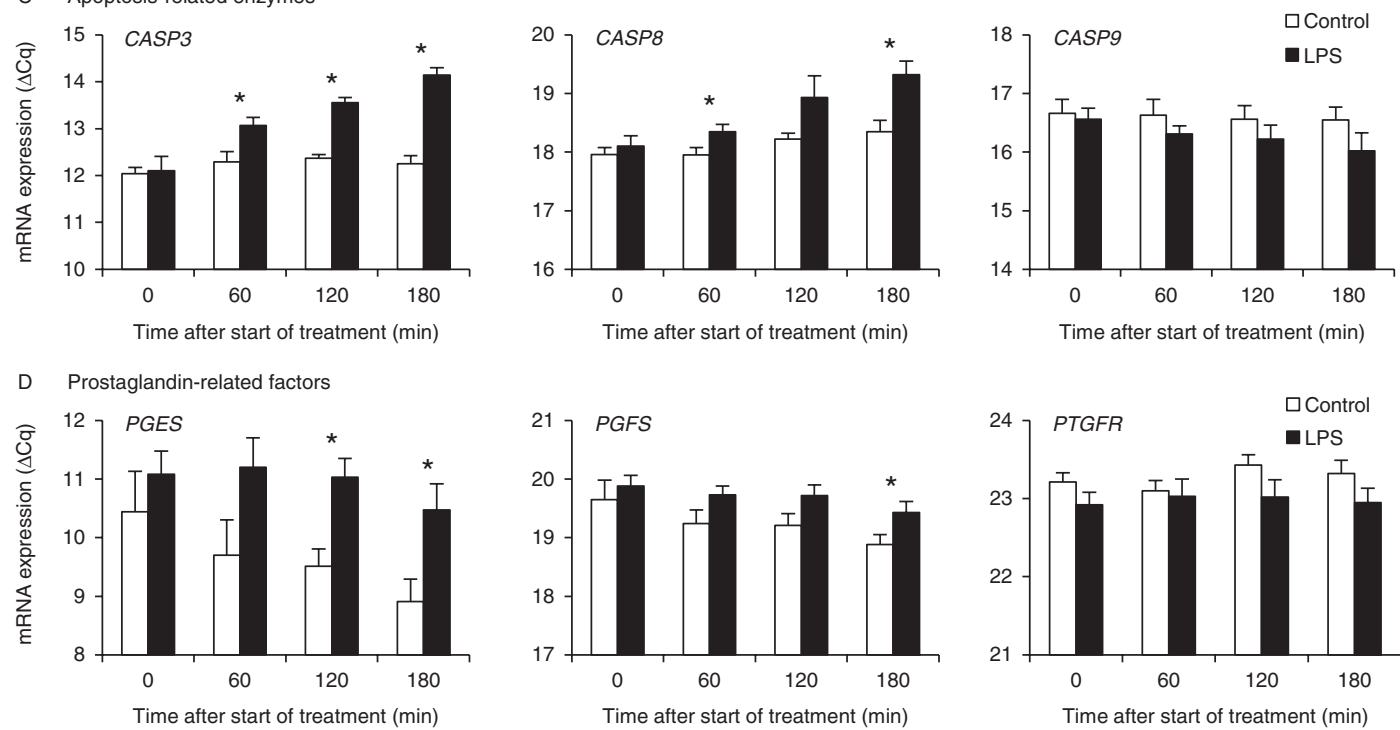

Time after start of treatment (min)

Time after start of treatment ( $\mathrm{min})$
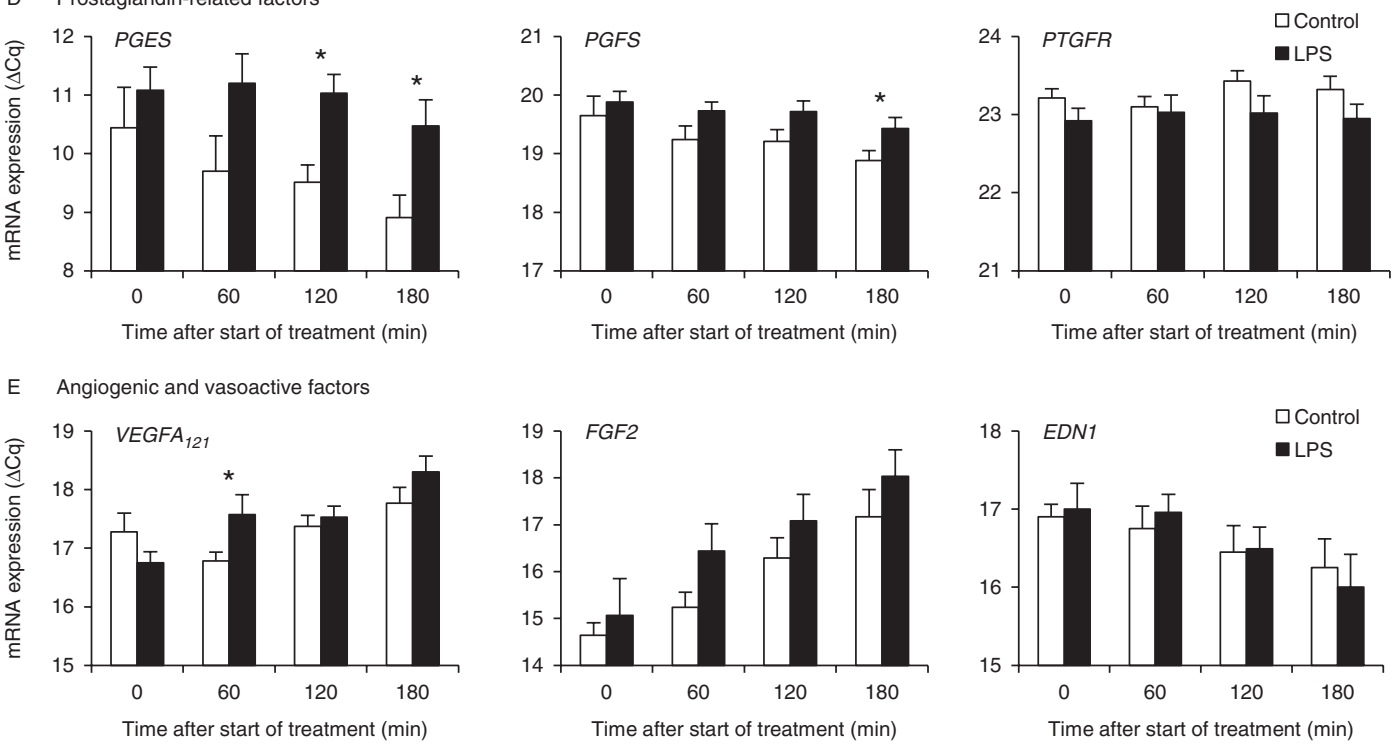

Figure 7 Changes (means \pm S.E.M.) in luteal mRNA expression of steroidogenic acute regulatory protein (STAR), 3-beta-hydroxysteroid dehydrogenase $(H S D 3 B)$, luteinizing hormone/choriogonadotropin receptor (LHCGR), caspase (CASP) 3, CASP8, CASP9, tumor necrosis factor alpha (TNFA), toll-like receptor (TLR) 2, TLR4, prostaglandin E synthase (PGES), PGFS, prostaglandin F receptor (PTGFR), vascular endothelial growth factor A isoform $121\left(V^{2} E F A_{121}\right)$, fibroblast growth factor 2 (FGF2), and endothelin 1 (EDN1) of control ovaries (white columns; $\left.n=6\right)$ and ovaries treated with LPS (black columns; $n=5)$ during the treatment period of perfusion. *Difference between groups $(P \leq 0.05)$ at times indicated.

not from leakage of $\mathrm{P}_{4}$ already present in the $\mathrm{CL}$ prior to perfusion (Dharmarajan et al. 1988). Furthermore, concentrations of $\mathrm{P}_{4}$ in the perfusate corresponded well with those synthesized in the tissue of $\mathrm{CL}$ from isolated perfused ovaries (Brannstrom \& Flaherty 1995), which were regarded as evidence of adequate 
secretory capacity. However, our results were not consistent with an initial increase (within $30 \mathrm{~min}$ ) and subsequent decline (until $9 \mathrm{~h}$ ) of $\mathrm{P}_{4}$ concentrations in an in vivo study involving cows given LPS by intravenous treatment (Herzog et al. 2012). Notwithstanding, our results supported the assertion that the initial increase in $\mathrm{P}_{4}$ after treatment with LPS in vivo might be of adrenal origin due to activation of a neuroendocrine stress axis (Kujjo et al. 1995, Herzog et al. 2012).

Since LH or hCG significantly increase $\mathrm{P}_{4}$ production in bovine mid-cycle CL (Koos et al. 1984, Litch \& Condon 1988), an hCG challenge was used in the present study to assess secretory capacity of the $\mathrm{CL}$ during isolated perfusion. It was noteworthy that $\mathrm{P}_{4}$ increased significantly $30 \mathrm{~min}$ after application of hCG in the control, but not in the LPS group. In cattle, LH binds to its specific receptor LHCGR and ultimately increases synthesis of STAR and activity of cytochrome P450scc and HSD3B, followed by an increase in $\mathrm{P}_{4}$ secretion (Rekawiecki et al. 2005). However, in control ovaries in the present study, mRNA expressions of LHCGR, STAR and HSD3B were not increased $30 \mathrm{~min}$ after hCG challenge, although $\mathrm{P}_{4}$ concentrations were already higher at that time. Consistently, concentrations of mRNA for STAR, and HSD3B (measured at 3-h intervals) were not increased until $6 \mathrm{~h}$ after luteal cell stimulation with LH (Rekawiecki et al. 2005). Furthermore, $\mathrm{LH}$ responsiveness seemed to be more dependent on the extent of desensitization of luteal cells to LH (e.g., by extensive clustering and internalization of the receptor complex) than on the number of $\mathrm{LH}$ receptors, as during functional luteolysis, luteal cells apparently became desensitized to $\mathrm{LH}$, despite maintenance of LHCGR (Amsterdam et al. 2002). However, we inferred that the absence of an increase in $\mathrm{P}_{4}$ concentrations after LPS challenge was due to inhibited luteal release rather than synthesis of $\mathrm{P}_{4}$. Release of $\mathrm{P}_{4}$ from the ovine $\mathrm{CL}$ was regulated by calcium-dependent depolarization of the luteal cell membrane after stimulation with $\mathrm{LH}$ in vitro (Higuchi et al. 1976).

Moreover, luteal PGF $_{2 \alpha}$ concentrations in LPS-treated ovaries did not increase significantly, although there was a trend toward significance. The release of $\mathrm{PGF}_{2 \alpha}$ from the uterus is essential to suppress $\mathrm{P}_{4}$ concentrations during luteolysis at the end of the estrous cycle (McCracken et al. 1981). Whereas uterine $\mathrm{PGF}_{2 \alpha}$ has been clearly linked to luteolysis (Schams \& Berisha 2004), it is a debatable point whether luteal $\mathrm{PGF}_{2 \alpha}$ had a luteolytic effect in the present study. However, changes in luteal mRNA expressions in ovaries of the LPS group do not resemble changes observed after exogenous $\mathrm{PGF}_{2 \alpha}$ treatment in cows, including decreased mRNA expressions of PTGFR, steroidogenic (STAR, HSD3B) and angiogenic factors (VEGF, FGF2), and increased vasoactive factor EDN1 mRNA expression (Shirasuna et al. 2010). In the present study, there were no significant differences in these parameters between control and LPS ovaries, except for a temporary increase in $V E G F A_{121}$, indicating a non-specific response to LPS challenge. Therefore, we inferred that luteal $\mathrm{PGF}_{2 \alpha}$ was probably not primarily responsible for LPS-induced changes in the present study.

Tumor necrosis factor alpha is a potent stimulator of luteal synthesis of prostaglandins (including luteolytic $\mathrm{PGF}_{2 \alpha}$ and luteotropic $\mathrm{PGE}_{2}$ ), consistent with increased mRNA expressions of PGES at 120 and $180 \mathrm{~min}$ and PGFS at $180 \mathrm{~min}$ after the start of LPS treatment compared to control ovaries, similar to a previous report (Okuda et al. 1999). In bovine endometrial cells, $\mathrm{PGE}_{2}$ and $\mathrm{PGF}_{2 \alpha}$ production were elevated after LPS challenge (Herath et al. 2006), in association with extended luteal phases and premature regression of the $\mathrm{CL}$, respectively (Opsomer et al. 2000). The predominant effect (luteotropic or luteolytic) was dependent on $\mathrm{PGE}_{2}$ to $\mathrm{PGF}_{2 \alpha}$ ratio (Herath et al. 2006) and luteal phase (Shirasuna et al. 2010), with $\mathrm{PGE}_{2}$ primarily controlling the early and $\mathrm{PGF}_{2 \alpha}$ the mid- and late luteal phases, respectively. In the present study using mid-luteal $\mathrm{CL}$, increased mRNA expression of PGFS in the LPS group compared to the control group might have contributed to lower $\mathrm{P}_{4}$ concentrations after hCG challenge in LPS-treated ovaries. Bovine PGFS mRNA encodes for 20 $\alpha$-hydroxysteroid dehydrogenase (20 $\alpha$-HSD; Madore et al. 2003, Schuler et al. 2006) that is responsible for $\mathrm{P}_{4}$ catabolism within the $\mathrm{CL}$ (Naidansuren et al. 2011), and therefore might decrease $\mathrm{P}_{4}$ in the effluent perfusate. Furthermore, luteal cells that express $20 \alpha-$ HSD not only lose their capacity to secrete $\mathrm{P}_{4}$, but also facilitate expression of the death receptor Fas on their surface (Stocco et al. 2007), thereby enhancing apoptosis.

The main receptor for recognition of LPS is TLR4 (Akira 2003), whereas TLR2 predominantly recognizes peptidoglycans and lipoteichoic acid (Takeuchi et al. 1999). Expression of both receptors was reported in bovine ovaries (Vahanan et al. 2008). Interestingly, mRNA expression of TLR4 did not differ significantly between control and LPS-treated ovaries in the present study, whereas expression of TLR2 was higher in the LPS than in the control group $180 \mathrm{~min}$ after the start of treatment. Binding of the respective pathogens to TLR2 and -4 initiated a signaling cascade that resulted in release of TNFA and other cytokines (Kannaki et al. 2011). Since TNFA increased TLR2 mRNA expression in various murine (Matsumura et al. 2000) and human (Davanian et al. 2012) tissues, an involvement of TNFA in higher mRNA abundance of TLR2 after LPS challenge may have occurred in the present study.

In conclusion, treatment with LPS inhibited hCGinduced $\mathrm{P}_{4}$ secretion in the bovine $C L$. The reduced $\mathrm{P}_{4}$ secretion seemed to be predominantly caused by an increase in LPS-induced apoptosis, but not by decreased steroidogenic factors. Regardless, an impact of luteal $\mathrm{PGF}_{2 \alpha}$ could not be excluded. 


\section{Declaration of interest}

The authors declare that there is no conflict of interest that could be perceived as prejudicing the impartiality of the research reported.

\section{Funding}

This research did not receive any specific grant from any funding agency in the public, commercial or not-for-profit sectors.

\section{Acknowledgements}

The authors acknowledge Prof. Dr M Kietzmann and Prof. Dr J Vogel for giving helpful advice regarding technical aspects of the isolated perfusion of organs. Furthermore, they thank $\mathrm{P}$ Egli and S Peterhans for their assistance during collection, preparation, and perfusion of the ovaries and $Y$ Zbinden and $C$ Philipona for laboratory work. The authors also acknowledge $M$ Siuda and Prof. Dr F Janett for organization of reagents and the cryoconservation of biopsy samples, respectively, and $\operatorname{Dr} C$ Bauer for permission to collect ovaries at the abattoir in Zurich.

\section{References}

Ahren K, Janson PO \& Selstam G 1972 Perfusion of ovaries in vitro and in vivo. Acta Endocrinologica. Supplementum (Copenh) 158 285-309.

Akira S 2003 Mammalian toll-like receptors. Current Opinion in Immunology 15 5-11. (doi:10.1016/S0952-7915(02)00013-4)

Amsterdam A, Hanoch T, Dantes A, Tajima K, Strauss JF \& Seger R 2002 Mechanisms of gonadotropin desensitization. Molecular and Cellular Endocrinology 187 69-74. (doi:10.1016/S0303-7207(01)00701-8)

Barker AR, Schrick FN, Lewis MJ, Dowlen HH \& Oliver SP 1998 Influence of clinical mastitis during early lactation on reproductive performance of Jersey cows. Journal of Dairy Science 81 1285-1290. (doi:10.3168/jds. S0022-0302(98)75690-5)

Benyo DF \& Pate JL 1992 Tumor necrosis factor- $\alpha$ alters bovine luteal cell synthetic capacity and viability. Endocrinology 130 854-860. (doi:10.1210/endo.130.2.1733731)

Bjersing L, Cajander S, Damber JE, Janson PO \& Kallfelt B 1981 The isolated perfused rabbit ovary-a model for studies of ovarian function. Ultrastructure after perfusion with different media. Cell and Tissue Research 216 471-479. (doi:10.1007/BF00238644)

Blum JW, Dosogne H, Hoeben D, Vangroenweghe F, Hammon HM, Bruckmaier RM \& Burvenich C 2000 Tumor necrosis factor- $\alpha$ and nitrite/nitrate responses during acute mastitis induced by Escherichia coli infection and endotoxin in dairy cows. Domestic Animal Endocrinology 19 223-235. (doi:10.1016/S0739-7240(00)00079-5)

Brannstrom M \& Flaherty S 1995 Methodology and characterization of an in vitro perfusion model for the mouse ovary. Journal of Reproduction and Fertility 105 177-183. (doi:10.1530/jrf.0.1050177)

Davanian H, Bage T, Lindberg J, Lundeberg J, Concha HQ, Saellberg Chen M \& Yucel-Lindberg T 2012 Signaling pathways involved in the regulation of TNF $\alpha$-induced toll-like receptor 2 expression in human gingival fibroblasts. Cytokine 57 406-416. (doi:10.1016/j.cyto. 2011.12.008)

Dharmarajan AM, Yoshimura Y, Sueoka K, Atlas SJ, Dubin NH, Ewing LL, Zirkin BR \& Wallach EE 1988 Progesterone secretion by corpora lutea of the isolated perfused rabbit ovary during pseudopregnancy. Biology of Reproduction 38 1137-1143. (doi:10.1095/biolreprod38.5.1137)

Giri SN, Emau P, Cullor JS, Stabenfeldt GH, Bruss ML, Bondurant RH \& Osburn BI 1990 Effects of endotoxin infusion on circulating levels of eicosanoids, progesterone, cortisol, glucose and lactic acid, and abortion in pregnant cows. Veterinary Microbiology 21 211-231. (doi:10.1016/ 0378-1135(90)90033-R)
Giri SN, Stabenfeldt GH, Moseley TA, Graham TW, Bruss ML, BonDurant RH, Cullor JS \& Osburn BI 1991 Role of eicosanoids in abortion and its prevention by treatment with flunixin meglumine in cows during the first trimester of pregnancy. Zentralblatt für Veterinärmedizin. Reihe A 38 445-459.

Hansen PJ, Soto P \& Natzke RP 2004 Mastitis and fertility in cattle possible involvement of inflammation or immune activation in embryonic mortality. American Journal of Reproductive Immunology 51 294-301. (doi:10.1111/j.1600-0897.2004.00160.x)

Herath S, Fischer DP, Werling D, Williams EJ, Lilly ST, Dobson H, Bryant CE \& Sheldon IM 2006 Expression and function of toll-like receptor 4 in the endometrial cells of the uterus. Endocrinology 147 562-570. (doi:10.1210/en.2005-1113)

Herzog K, Brockhan-Lüdemann M, Kaske M, Beindorff N, Paul V, Niemann H \& Bollwein H 2010 Luteal blood flow is a more appropriate indicator for luteal function during the bovine estrous cycle than luteal size. Theriogenology 73 691-697. (doi:10.1016/j.theriogenology.2009. 11.016)

Herzog K, Strüve K, Kastelic JP, Piechotta M, Ulbrich SE, Pfarrer C, Shirasuna K, Shimizu T, Miyamoto A \& Bollwein H 2012 Escherichia coli lipopolysaccharide administration transiently suppresses luteal structure and function in diestrous cows. Reproduction 144 467-476. (doi:10.1530/REP-12-0138)

Higuchi T, Kaneko A, Abel JH Jr \& Niswender GD 1976 Relationship between membrane potential and progesterone release in ovine corpora lutea. Endocrinology 99 1023-1032. (doi:10.1210/endo-99-4-1023)

Holmes PV, Sogn J, Schillinger E \& Janson PO 1985 Effects of high and low preovulatory concentrations of progesterone on ovulation from the isolated perfused rabbit ovary. Journal of Reproduction and Fertility $\mathbf{7 5}$ 393-399. (doi:10.1530/jrf.0.0750393)

Janson PO, Amato F, Weiss TJ, Ralph MM \& Seamark RF 1978 On the isolated perfused sheep ovary as a model for the study of ovarian function. Fertility and Sterility 30 230-236.

Kannaki TR, Shanmugam M \& Verma PC 2011 Toll-like receptors and their role in animal reproduction. Animal Reproduction Science 125 1-12. (doi:10.1016/j.anireprosci.2011.03.008)

Koos RD, Jaccarino FJ, Magaril RA \& Le Maire WJ 1984 Perfusion of the rat ovary in vitro: methodology, induction of ovulation, and pattern of steroidogenesis. Biology of Reproduction 30 1135-1141. (doi:10.1095/ biolreprod30.5.1135)

Kujjo LL, Bosu WT \& Perez GI 1995 Opioid peptides involvement in endotoxin-induced suppression of $\mathrm{LH}$ secretion in ovariectomized Holstein heifers. Reproductive Toxicology 9 169-174. (doi:10.1016/ 0890-6238(94)00068-9)

Kushibiki S 2011 Tumor necrosis factor- $\alpha$-induced inflammatory responses in cattle. Animal Science Journal 82 504-511. (doi:10.1111/j.17400929.2011.00931.x)

Lavon Y, Leitner G, Goshen T, Braw-Tal R, Jacoby S \& Wolfenson D 2008 Exposure to endotoxin during estrus alters the timing of ovulation and hormonal concentrations in cows. Theriogenology 70 956-967. (doi:10.1016/j.theriogenology.2008.05.058)

LeBlanc SJ, Duffield TF, Leslie KE, Bateman KG, Keefe GP, Walton JS \& Johnson WH 2002 Defining and diagnosing postpartum clinical endometritis and its impact on reproductive performance in dairy cows. Journal of Dairy Science 85 2223-2236. (doi:10.3168/jds.S00220302(02)74302-6)

Litch SJ \& Condon WA 1988 Interaction of hCG and Lutalyse on steroidogenesis of bovine luteal cells. Molecular and Cellular Endocrinology 57 81-85. (doi:10.1016/0303-7207(88)90035-4)

Livak KJ \& Schmittgen TD 2001 Analysis of relative gene expression data using real-time quantitative PCR and the $2(-\Delta \Delta C(\mathrm{~T}))$ Method. Methods 25 402-408. (doi:10.1006/meth.2001.1262)

Madore E, Harvey N, Parent J, Chapdelaine P, Arosh JA \& Fortier MA 2003 An aldose reductase with $20 \alpha$-hydroxysteroid dehydrogenase activity is most likely the enzyme responsible for the production of prostaglandin $\mathrm{F} 2 \alpha$ in the bovine endometrium. Journal of Biological Chemistry 278 11205-11212. (doi:10.1074/jbc.M208318200)

Matsumura T, Ito A, Takii T, Hayashi H \& Onozaki K 2000 Endotoxin and cytokine regulation of toll-like receptor (TLR) 2 and TLR4 gene expression in murine liver and hepatocytes. Journal of Interferon \& Cytokine Research 20 915-921. (doi:10.1089/10799900050163299) 
McCracken JA, Schramm W, Barcikowski B \& Wilson L Jr 1981 The identification of prostaglandin $\mathrm{F} 2 \alpha$ as a uterine luteolytic hormone and the hormonal control of its synthesis. Acta veterinaria Scandinavica. Supplementum 77 71-88.

McCracken JA, Custer EE \& Lamsa JC 1999 Luteolysis: a neuroendocrinemediated event. Physiological Reviews 79 263-323.

Mills RC \& Morrissette MC 1970 Progesterone synthesis by perfused bovine ovaries of early and late pregnancy. Journal of Reproduction and Fertility 22 435-440. (doi:10.1530/jrf.0.0220435)

Mishra DP \& Dhali A 2007 Endotoxin induces luteal cell apoptosis through the mitochondrial pathway. Prostaglandins \& Other Lipid Mediators 83 75-88. (doi:10.1016/j.prostaglandins.2006.10.002)

Miyamoto Y, Skarzynski DJ \& Okuda K 2000 Is tumor necrosis factor $\alpha$ a trigger for the initiation of endometrial prostaglandin $\mathrm{F}(2 \alpha)$ release at luteolysis in cattle? Biology of Reproduction 62 1109-1115. (doi:10.1095/biolreprod62.5.1109)

Miyamoto A, Shirasuna K \& Sasahara K 2009 Local regulation of corpus luteum development and regression in the cow: Impact of angiogenic and vasoactive factors. Domestic Animal Endocrinology 37 159-169. (doi:10.1016/j.domaniend.2009.04.005)

Naidansuren P, Park CW, Kim SH, Nanjidsuren T, Park JJ, Yun SJ, Sim BW, Hwang S, Kang MH, Ryu BY et al. 2011 Molecular characterization of bovine placental and ovarian 20 $\alpha$-hydroxysteroid dehydrogenase. Reproduction 142 723-731. (doi:10.1530/REP-11-0093)

Okuda K \& Sakumoto R 2003 Multiple roles of TNF super family members in corpus luteum function. Reproductive Biology and Endocrinology 1 95. (doi:10.1186/1477-7827-1-95)

Okuda K, Sakumoto R, Uenoyama Y, Berisha B, Miyamoto A \& Schams D 1999 Tumor necrosis factor $\alpha$ receptors in microvascular endothelial cells from bovine corpus luteum. Biology of Reproduction $\mathbf{6 1}$ 1017-1022. (doi:10.1095/biolreprod61.4.1017)

Opsomer G, Groehn YT, Hertl J, Coryn M, Deluyker H \& de Kruif A 2000 Risk factors for post partum ovarian dysfunction in high producing dairy cows in Belgium: A field study. Theriogenology 53 841-857. (doi:10.1016/S0093-691X(00)00234-X)

Rekawiecki R, Nowik M \& Kotwica J 2005 Stimulatory effect of LH, PGE2 and progesterone on StAR protein, cytochrome P450 cholesterol side chain cleavage and $3 \beta$ hydroxysteroid dehydrogenase gene expression in bovine luteal cells. Prostaglandins \& Other Lipid Mediators 78 169-184. (doi:10.1016/j.prostaglandins.2005.06.009)

Rekawiecki R, Kowalik MK, Slonina D \& Kotwica J 2008 Regulation of progesterone synthesis and action in bovine corpus luteum. Journal of Physiology and Pharmacology 59 (Suppl 9) 75-89.

Richter O, Wardelmann E, Dombrowski F, Schneider C, Kiel R, Wilhelm K, Schmolling J, Kupka M, van der Ven H \& Krebs D 2000 Extracorporeal perfusion of the human uterus as an experimental model in gynaecology and reproductive medicine. Human Reproduction 15 1235-1240. (doi:10.1093/humrep/15.6.1235)

Romanoff EB \& Pincus G 1962 Studies of the isolated perfused ovary: methods and examples of application. Endocrinology 71 752-755. (doi:10.1210/endo-71-5-752)

Sakumoto R, Vermehren M, Kenngott RA, Okuda K \& Sinowatz F 2011 Localization of gene and protein expressions of tumor necrosis factor- $\alpha$ and tumor necrosis factor receptor types I and II in the bovine corpus luteum during the estrous cycle. Journal of Animal Science 89 3040-3047. (doi:10.2527/jas.2010-3479)

Schams D \& Berisha B 2004 Regulation of corpus luteum function in cattle an overview. Reproduction in domestic animals = Zuchthygiene 39 241-251. (doi:10.1111/j.1439-0531.2004.00509.x)

Schuler G, Teichmann U, Kowalewski MP, Hoffmann B, Madore E, Fortier MA \& Klisch K 2006 Expression of cyclooxygenase-II (COX-II) and 20 $\alpha$-hydroxysteroid dehydrogenase (20 $\alpha$-HSD)/prostaglandin F-synthase (PGFS) in bovine placentomes: implications for the initiation of parturition in cattle. Placenta 27 1022-1029. (doi:10.1016/j.placenta. 2005.11.001)

Shirasuna K, Asaoka H, Acosta TJ, Wijayagunawardane MP, Ohtani M, Hayashi KG, Matsui M \& Miyamoto A 2004 Real-time dynamics of prostaglandin $\mathrm{F} 2 \alpha$ release from uterus and corpus luteum during spontaneous luteolysis in the cow. Reproduction 128 189-195. (doi:10.1530/rep.1.00183)

Shirasuna K, Sasahara K, Matsui M, Shimizu T \& Miyamoto A 2010 Prostaglandin F2 $\alpha$ differentially affects mRNA expression relating to angiogenesis, vasoactivation and prostaglandins in the early and mid corpus luteum in the cow. Journal of Reproduction and Development $\mathbf{5 6}$ 428-436. (doi:10.1262/jrd.10-004O)

Skarzynski DJ, Miyamoto Y \& Okuda K 2000 Production of prostaglandin F2 $\alpha$ by cultured bovine endometrial cells in response to tumor necrosis factor $\alpha$ : cell type specificity and intracellular mechanisms. Biology of Reproduction 62 1116-1120. (doi:10.1095/biolreprod62.5.1116)

Skarzynski DJ, Jaroszewski JJ \& Okuda K 2005 Role of tumor necrosis factor- $\alpha$ and nitric oxide in luteolysis in cattle. Domestic Animal Endocrinology 29 340-346. (doi:10.1016/j.domaniend.2005.02.005)

Skarzynski DJ, Woclawek-Potocka I, Korzekwa A, Bah MM, Piotrowska K, Barszczewska B \& Okuda K 2007 Infusion of exogenous tumor necrosis factor dose dependently alters the length of the luteal phase in cattle: differential responses to treatment with indomethacin and L-NAME, a nitric oxide synthase inhibitor. Biology of Reproduction 76 619-627. (doi:10.1095/biolreprod.106.053280)

Skarzynski DJ, Ferreira-Dias G \& Okuda K 2008 Regulation of luteal function and corpus luteum regression in cows: hormonal control, immune mechanisms and intercellular communication. Reproduction in domestic animals = Zuchthygiene 43 (Suppl 2) 57-65. (doi:10.1111/ j.1439-0531.2008.01143.x)

Stahler E \& Huch A 1971 Studies of the isolated perfused bovine ovaries. Archiv für Gynäkologie 211 527-544.

Stocco C, Telleria C \& Gibori G 2007 The molecular control of corpus luteum formation, function, and regression. Endocrine Reviews 28 117-149. (doi:10.1210/er.2006-0022)

Sturm G \& Stahler E 1971 Studies on steroid biosynthesis of in-vitro perfused bovine ovaries in various functional phases. Archiv für Gynäkologie 211 545-557.

Suzuki C, Yoshioka K, Iwamura S \& Hirose H 2001 Endotoxin induces delayed ovulation following endocrine aberration during the proestrous phase in Holstein heifers. Domestic Animal Endocrinology 20 267-278. (doi:10.1016/S0739-7240(01)00098-4)

Takeuchi O, Hoshino K, Kawai T, Sanjo H, Takada H, Ogawa T, Takeda K \& Akira S 1999 Differential roles of TLR2 and TLR4 in recognition of gramnegative and gram-positive bacterial cell wall components. Immunity 11 443-451. (doi:10.1016/S1074-7613(00)80119-3)

Ulbrich SE, Schulke K, Groebner AE, Reichenbach HD, Angioni C, Geisslinger G \& Meyer HH 2009 Quantitative characterization of prostaglandins in the uterus of early pregnant cattle. Reproduction 138 371-382. (doi:10.1530/REP-09-0081)

Vahanan BM, Raj GD, Pawar RM, Gopinath VP, Raja A \& Thangavelu A 2008 Expression profile of toll like receptors in a range of water buffalo tissues (Bubalus bubalis). Veterinary Immunology and Immunopathology 126 149-155. (doi:10.1016/j.vetimm.2008.05.027)

Walsh SW, Williams EJ \& Evans AC 2011 A review of the causes of poor fertility in high milk producing dairy cows. Animal Reproduction Science 123 127-138. (doi:10.1016/j.anireprosci.2010.12.001)

Williams EJ, Sibley K, Miller AN, Lane EA, Fishwick J, Nash DM, Herath S, England GC, Dobson H \& Sheldon IM 2008 The effect of Escherichia coli lipopolysaccharide and tumour necrosis factor $\alpha$ on ovarian function. American Journal of Reproductive Immunology 60 462-473. (doi:10.1111/j.1600-0897.2008.00645.x)

Received 22 June 2015

First decision 16 July 2015

Revised manuscript received 15 September 2015

Accepted 19 October 2015 